\title{
TREATMENT OF HUMERAL SHAFT FRACTURES: ANTEGRADE INTERLOCKING INTRAMEDULLARY NAILING WITH ADDITIONAL INTERLOCKING NEUTRALIZATION SCREWS THROUGH FRACTURE SITE
}

\author{
Dinko Vidović ${ }^{1,3}$, Ivan Benčić ${ }^{1}$,Tomislav Ćuti ${ }^{1}$, Domagoj Gajski ${ }^{8}$, Tomislav Čengic ${ }^{1,6}$, \\ Marijo Bekić ${ }^{7}$, Mario Zovak ${ }^{2,3,4}$, Srećko Sabalić ${ }^{1,5}$ and Dejan Blaževićc ${ }^{1,6}$ \\ ${ }^{1}$ Department of Traumatology, Sestre milosrdnice University Hospital Centre, Zagreb, Croatia; \\ ${ }^{2}$ Department of Surgery, Sestre milosrdnice University Hospital Centre, Zagreb, Croatia; \\ ${ }^{3}$ School of Dental Medicine, University of Zagreb, Zagreb, Croatia; \\ ${ }^{4}$ School of Medicine, University of Zagreb, Zagreb, Croatia; \\ ${ }^{5}$ School of Medicine, University of Split, Split, Croatia; \\ ${ }^{6}$ University of Applied Health Sciences, Zagreb, Croatia; \\ ${ }^{7}$ Orthopedic and Traumatology Department, Dubrovnik General Hospital, Dubrovnik, Croatia; \\ ${ }^{8}$ Department of Neurosurgery, Sestre milosrdnice University Hospital Centre, Zagreb, Croatia
}

SUMMARY - The aim of this study was to compare union time between two different nail designs for the treatment of humeral shaft fracture, i.e. antegrade interlocking intramedullary nail with and without additional interlocking neutralization screws. The retrospective study included $51 \mathrm{pa}^{-}$ tients treated with antegrade humeral intramedullary nailing between January 2015 and December 2017. The inclusion criteria of the study were proximal and middle third humeral shaft fractures. Fifty-one patients met the inclusion criteria; 23 patients were treated with antegrade intramedullary nail with additional interlocking neutralization screws through fracture site (group A) and 28 patients were treated with antegrade intramedullary nail without additional interlocking neutralization screws (group B). Medical documentation and radiographic images taken preoperatively and postoperatively were reviewed. Radiological union was defined as cortical bridging of at least three of four cortices in two-plane radiographs, with disappearance of the fracture gap. There were no significant differences in union time between the groups ( $p>0.05)$. To our knowledge, this is the first report of antegrade interlocking humeral nailing with additional interlocking neutralization screws through fracture site. Hypothetical advantages of fracture gap reduction by additional interlocking neutralization screws to promote union were not confirmed by this first clinical trial.

Key words: Humerus; Humeral fractures; Fracture fixation, intramedullary; Bone and bones

\section{Introduction}

Humeral shaft fractures account for up to $3 \%$ of all fractures and $20 \%$ of all fractures of the humerus ${ }^{1,2}$. Humeral shaft fracture incidence is bimodal, with the first peak in young males as the result of high-energy trauma, and the second most prominent peak in wom-
Correspondence to: Asst. Prof. Dinko Vidovic, MD, PhD. Department of Traumatology, Sestre milosrdnice University Hospital Centre, Vinogradska c. 29, HR-10000 Zagreb, Croatia, School of Dental Medicine, University of Zagreb, Zagreb, Croatia E-mail: dinko.vidovic@gmail.com

Received December 3, 2018, accepted January 7, 2019 
en between sixty and eighty years of age, as the result of low-energy trauma ${ }^{3,4}$. Humeral shaft fractures can be treated conservatively and operatively. Conservative treatment has been proven as an excellent method with very low complication rate ${ }^{5}$. However, some fracture patterns are not suitable for conservative treatment such as periarticular and long spiral fractures. It has to be emphasized that the outcome of conservative treatment is strongly influenced by patient compliance as well ${ }^{6,7}$. Internal fixation can be performed via intramedullary nailing or plating. Intramedullary nailing has shown some advantages in terms of biological fixation with preservation of blood supply ${ }^{8}$. Intramedullary nail is a load-sharing device and should be considered as the treatment of choice for pathological fractures as well ${ }^{9}$. There are two insertion possibilities of humeral intramedullary nails: antegrade insertion with entry point at the shoulder and retrograde insertion with entry point at the elbow, each associated with entry site morbidity ${ }^{10}$. Many authors still consider osteosynthesis with plate as the gold standard because they refer to complications associated with the old design of noninterlocking nails in previous studies ${ }^{11-14}$. However, contemporary interlocking nails showed similar results in fracture healing in comparison with plating $^{15,16}$. It can be difficult to perform closed reduction or obtain the required stability from fixation with an intramedullary nail in highly unstable fractures of the humeral shaft in which there are complex or severely displaced fragments, and such difficulties could result in delayed union or non-union ${ }^{17}$. In our study, it was hypothesized that using interlocking neutralization screws through fracture site would improve stability and reduce fracture gap, thus promoting union. The aim of this study was to compare union time between two different nail designs, i.e. antegrade interlocking intramedullary nail with and without additional interlocking neutralization screws.

\section{Patients and Methods}

The present retrospective study included $51 \mathrm{pa}^{-}$ tients treated with antegrade humeral intramedullary nailing between January 2015 and December 2017 at Department of Traumatology, Sestre milosrdnice University Hospital Centre in Zagreb, Croatia. The inclusion criteria of the present study were proximal and middle third humeral shaft fractures, whereas the ex- clusion criteria were non-unions, pathological and periprosthetic fractures. Patients were divided into group A treated with intramedullary nail with additional interlocking neutralization screws through fracture site and group B treated with intramedullary nail without neutralization screws. Proximal and distal interlocking screws were used in both groups. In group A, proximal interlocking screws and additional interlocking neutralization screws were inserted by targeting device according to the nail technical guidelines, and distal interlocking screws were inserted by freehand technique. Medical documentation and radiographic images taken preoperatively and postoperatively were reviewed. We analyzed union rate and time to union and delayed union. All fractures were classified using the Arbeitsgemeinschaft für Osteosynthesefragen/Orthopaedic Trauma Association (AO/ OTA) classification system by reviewing the radiographs ${ }^{18}$. Radiological union was defined as cortical bridging of at least three of four cortices in two-plane radiographs, with disappearance of the fracture gap ${ }^{19}$. Delayed union was defined as failure of radiological union at 4 months post fracture with no progress towards healing seen on the most recent radiographic images. Patients were followed-up for 6 months. The decision on intramedullary osteosynthesis with additional interlocking neutralization screws through fracture site or without neutralization screws was made by the attending surgeon, based upon his knowledge and expertise. Statistical analysis was performed by using the IBM SPSS Statistics version 23. Outcomes of union were compared between group A and group B, and were defined as categorical variables as follows: time to union $<4$ months and $>4$ months. Results of categorical variables were analyzed using the $\chi^{2}$ test or Fisher exact test if cell counts were less than five. The level of $\mathrm{p}<0.05$ was considered statistically significant.

\section{Results}

In total, 96 humeral shaft fractures were treated operatively. We excluded 45 patients mostly with insufficient follow up. This study included 51 patients: 23 patients were treated with antegrade intramedullary nail with additional neutralization screws through fracture site (group A) and 28 patients were treated with antegrade intramedullary nail without additional neutralization screws (group B). Representative radio- 


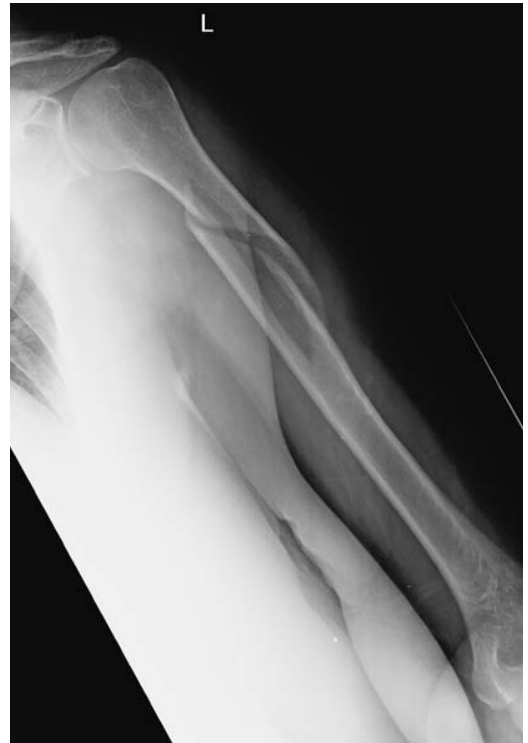

Fig. 1. Group A at admission.

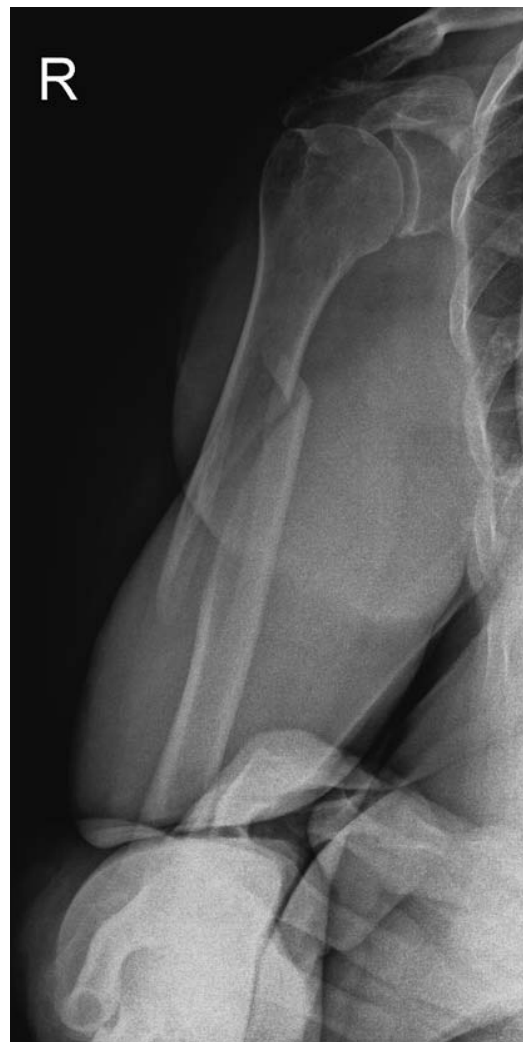

Fig. 4. Group B at admission.

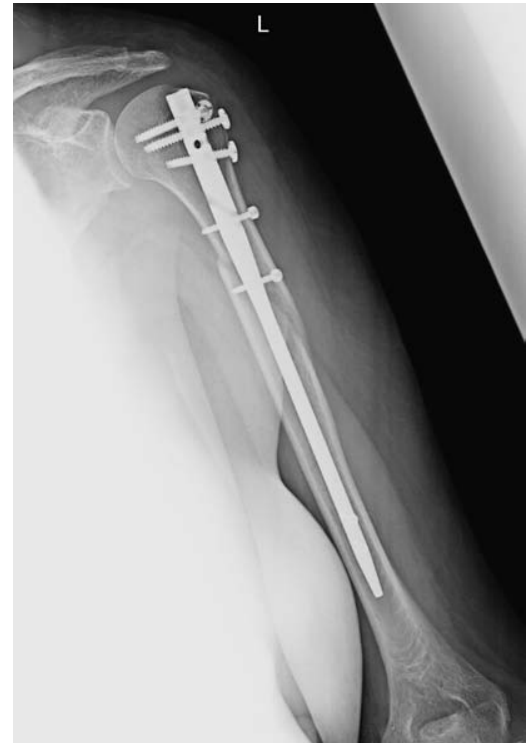

Fig. 2. Group A: one month postoperatively.

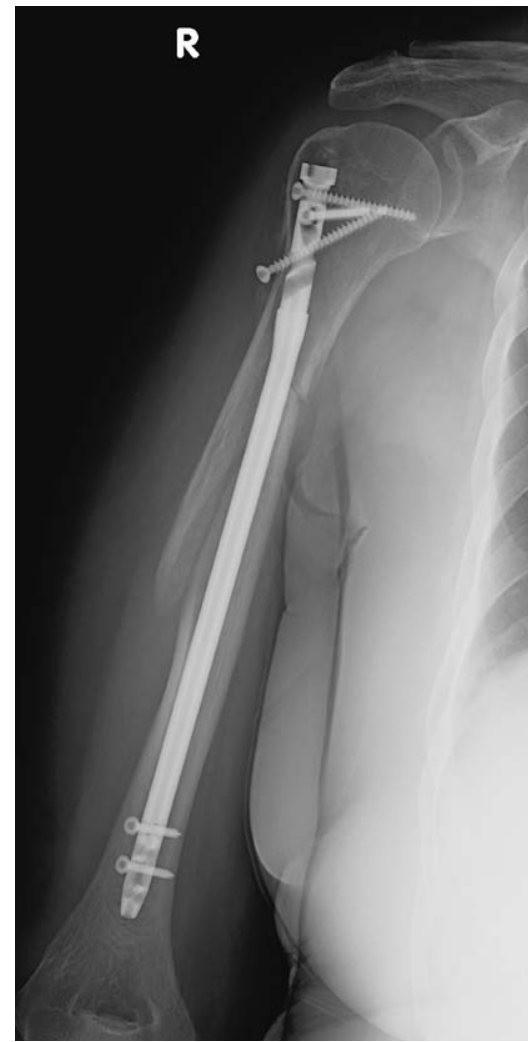

Fig. 5. Group B: one month postoperatively.

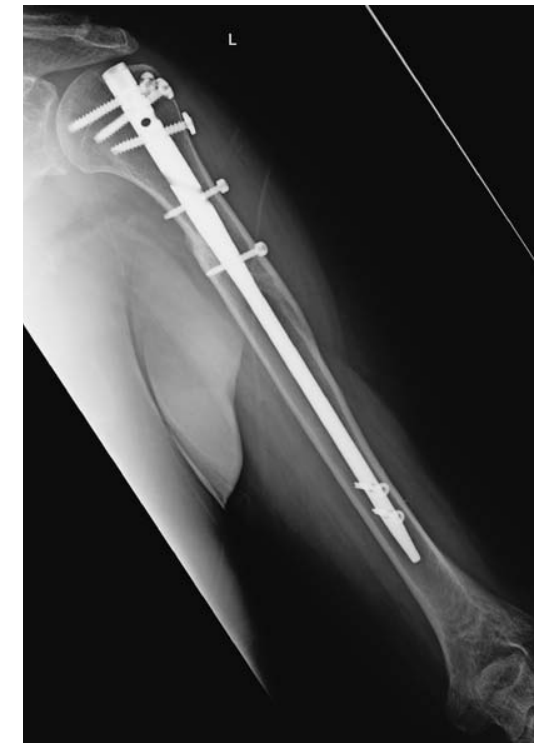

Fig. 3. Group A: final follow-up.

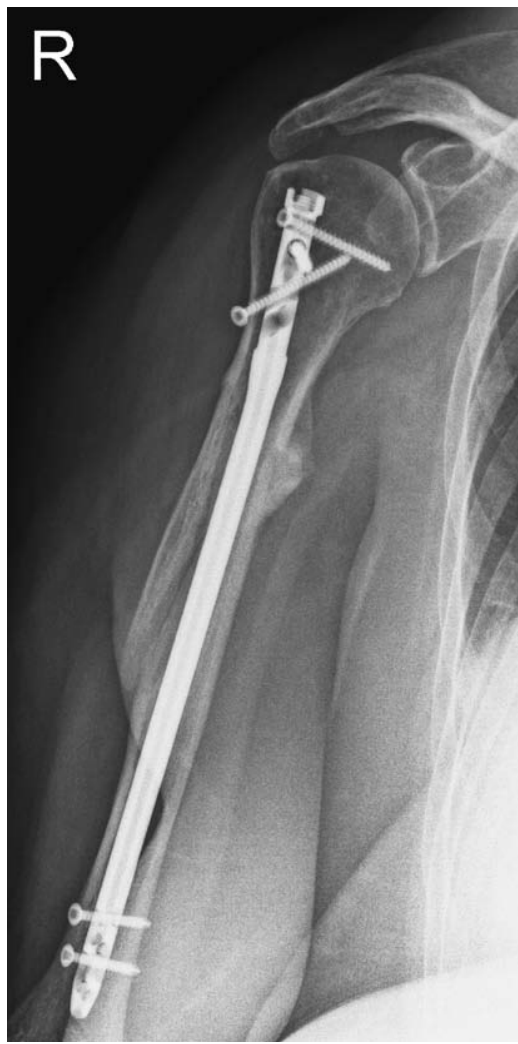

Fig. 6. Group B: final follow-up. graphs of group A patients and group B patients at admission, one month postoperatively, and at final follow up are shown in Figures 1-6.
The majority of patients were female $(60.8 \%)$ and the mean age at the time of injury for all patients was 61.3 years. 
Table 1 shows distribution of fractures according to AO types and subtypes. Type A humeral shaft fractures were most common (54.9\%) and type $\mathrm{C}$ least common (17.7\%). The A1 spiral humeral shaft fracture was the most common subtype (41.2\%).

The overall delayed union rate was $11.76 \%$. One patient with delayed union was in group $A$ and five patients with delayed union were in group B. In group A, patients with delayed union (A1 subtype) had transitory radial nerve palsy. In group $B$, four patients with delayed union (A1, A2, B1 and C3 subtypes of fracture) had proximal nail migration and one patient with delayed union (A3 subtype of fracture) had too short nail. Time to union did not differ significantly between the groups (Tables 2 and 3). There was a trend towards

\section{Table 1. Arbeitsgemeinschaft für Osteosynthesefragen} (AO) types and subtypes

\begin{tabular}{|l|l|l|l|l|l|}
\hline $\begin{array}{l}\text { AO } \\
\text { type }\end{array}$ & Frequency & Percent & $\begin{array}{l}\text { AO } \\
\text { subtype }\end{array}$ & Frequency & Percent \\
\hline A & 28 & \multirow{2}{*}{54.9} & A1 & 21 & 41.2 \\
& & A2 & 2 & 3.9 \\
A3 & 5 & 9.8 \\
\hline B & \multirow{2}{*}{14} & 27.4 & $\mathrm{~B} 1$ & 10 & 19.6 \\
& & B2 & 4 & 7.8 \\
\hline C & \multirow{2}{*}{9} & \multirow{2}{*}{17.7} & $\mathrm{C} 1$ & 7 & 13.7 \\
& & & $\mathrm{C} 2$ & 1 & 2.0 \\
\hline Total & 51 & 100.0 & Total & 51 & 2.0 \\
\hline
\end{tabular}

faster union time in group A; however, this trend was not statistically significant ( $\mathrm{p}=0.204$, two-sided Fisher exact test). Overall, we noted two cases of postoperative transitory radial nerve palsy that fully recovered within 6 months.

\section{Discussion}

The main operative goal of humeral shaft fractures is to restore alignment, length and rotation with stability that allows early motion ${ }^{20}$. Interlocked intramedullary nailing of humeral shaft fractures is one of the few possible treatment options for humeral shaft fractures. In early years, studies showed controversial results of humeral shaft fracture treatment comparing plating with nailing due to disadvantages of old intramedullary nail design ${ }^{21}$. For example, the Seidel nail had complications such as rotational instability and intraoperative fracture caused by insecure distal locking mechanism and too large nail head ${ }^{22}$. The later RusselTaylor nail had rotational instability due to discrepancy between the size of screw and the hole ${ }^{23}$. However, with improved nail designs and operative technique, more recent studies have reported satisfactory results with nailing ${ }^{15,16,24}$. Contemporary nails have demonstrated improved clinical results with proximal and distal multiple locking screws ${ }^{25-27}$. Proximal and distal interlocking screws tend to provide rotational stability and prevent shortening or lengthening of the humerus. Biomechanical studies have also shown that

Table 2. Type of intramedullary nail/time to union cross tabulation

\begin{tabular}{|c|c|c|c|c|}
\hline & \multicolumn{2}{|c|}{ Time to union } & \multirow[t]{2}{*}{ Total } \\
\hline & & $<4$ months & $>4$ months & \\
\hline \multirow[t]{2}{*}{$\begin{array}{l}\text { Type of intramedullary } \\
\text { nail }\end{array}$} & $\begin{array}{l}\text { Nail with additional interlocking } \\
\text { neutralization screws through fracture site }\end{array}$ & 22 & 1 & 23 \\
\hline & $\begin{array}{l}\text { Nail without additional interlocking } \\
\text { neutralization screws }\end{array}$ & 23 & 5 & 28 \\
\hline \multicolumn{2}{|l|}{ Total } & 45 & 6 & 51 \\
\hline
\end{tabular}

Table 3. $\chi^{2}$ and Fisher exact tests

\begin{tabular}{|l|l|l|l|l|l|}
\hline & Value & df & $\begin{array}{l}\text { Asymptotic significance } \\
(2 \text {-sided })\end{array}$ & Exact sig. (2-sided) & Exact sig. (1-sided) \\
\hline $\begin{array}{l}\chi^{2} \text { test } \\
\begin{array}{l}\text { Fisher exact test } \\
\text { Valid cases (n) }\end{array}\end{array}$ & $2.220^{\mathrm{a}}$ & 1 & 0.136 & 0.204 & 0.146 \\
\hline
\end{tabular}


interlocking nails ensure increased stability in comparison with non interlocking nails in rotationally unstable humeral fractures ${ }^{28}$. Distal interlocking of an antegrade humeral nail is more difficult than distal interlocking in the femur or tibia because of triangular distal humerus shape and lateral $\mathrm{x}$-ray view of the humerus cannot be easily obtained. Freehand distal interlocking of intramedullary nails requires a long learning curve and orthopedic surgeons have difficulty with it at the beginning of their professional career ${ }^{29}$. Humeral shaft fractures can be treated with antegrade or retrograde nail ${ }^{30}$. In our study, we performed antegrade nailing for proximal and middle third humeral shaft fractures because of insertion from the shorter to the longer fragment. Biomechanical studies showed increased stability if the nail was inserted from the shorter to the longer fragment ${ }^{10}$. The main complications of antegrade humeral nailing are nail migration, distraction, long proximal locking screws, additional diaphyseal fracture, rotator cuff pain and shoulder impingement $t^{31-33}$. In our study, the main complication was proximal nail migration with overall four cases in group B. Several studies demonstrated delayed union rates of $9 \%-19 \%$ after operative treatment ${ }^{34-36}$. Data from our study (11.76\%) are comparable with those found in current literature. Gender distribution (female 60.8\%) and $\mathrm{AO}$ fracture type distribution (A type $54.9 \%$ ) in our study is consistent with the current epidemiological literature ${ }^{1}$.

To our knowledge, this is the first report of antegrade interlocking humeral nailing with additional interlocking neutralization screws through fracture site. The application of additional interlocking neutralization screws is suitable for the fracture in the proximal third of the humeral shaft and for the long oblique and long spiral fracture in the middle third of the humeral shaft with extension in proximal third. By applying these screws, the fracture distraction can be prevented during humerus manipulation owing to inserting distal interlocking screws by freehand technique because the additional neutralization screws are placed near the fracture site by targeting device before the distal interlocking screws. Additional interlocking neutralization screws can prevent the postoperative complication of proximal nail migration, as suggested by the fact that there was no proximal nail migration in group A. The benefit of additional interlocking neutralization screws is fracture gap reduction without opening the fracture site, thus preserving blood supply and allowing biological fixation for some unstable humeral shaft fractures. Additional interlocking neutralization screws can promote union by reducing fracture gap as well. However, hypothetical advantages of fracture gap reduction by additional interlocking neutralization screws to promote union were not confirmed in this first clinical trial. The additional interlocking screw across fracture site acts as a positioning screw that neutralizes fragments, thus it does not apply any interfragmentary compression. However, this can be considered as a possible disadvantage that can interfere with fracture healing. Nevertheless, we did not observe such a complication, which might be explained by completely preserved blood supply that promotes fracture healing regardless of the screw applied through the fracture site. The limitation of our study was retrospective, nonrandomized study design. The decision on operative treatment between group A and group B was made by attending surgeon according to his preferences and previous experience. Data on the functional outcome and time to full resumption of daily activities were unavailable in this retrospective study. In conclusion, further randomized prospective study should be performed in a larger sample to evaluate time to union, functional outcome and time to early motion in correlation with reducing fracture gap by additional neutralization interlocking screws. A biomechanical study should be performed to examine the stability of interlocking intramedullary nail with additional interlocking neutralization screws in comparison with interlocking intramedullary nail without these screws.

\section{References}

1. Ekholm R, Adami J, Tidermark J, Hansson K, Törnkvist H, Ponzer S. Fractures of the shaft of the humerus. An epidemiological study of 401 fractures. J Bone Joint Surg Br. 2006 Nov;88(11):1469-73. doi: 10.1302/0301-620X.88B11.17634

2. Tsai CH, Fong YC, Chen YH, Hsu CJ, Chang CH, Hsu HC. The epidemiology of traumatic humeral shaft fractures in Taiwan. Int Orthop. 2009 Apr;33(2):463-7. doi: 10.1007/s00264008-0537-8

3. Attum B, Obremskey W. Treatment of humeral shaft fractures: a critical analysis review. JBJS Rev. 2015 Sep 29;3(9). doi: 10.2106/JBJS.RVW.N.00119

4. Gonçalves FF, Dau L, Grassi CA, Palauro FR, Martins Neto AA, Pereira PCG. Evaluation of the surgical treatment of humeral shaft fractures and comparison between surgical fixation 
methods. Rev Bras Ortop. 2018 Feb 27;53(2):136-41. doi: 10.1016/j.rboe.2017.03.015

5. Sarmiento A, Zagorski JB, Zych GA, Latta LL, Capps CA. Functional bracing for the treatment of fractures of the humeral diaphysis. J Bone Joint Surg Am. 2000 Apr;82(4): 478-86.

6. Verma A, Kushwaha SS, Khan YA, Mohammed F, Shekhar S, Goyal A. Clinical outcome of treatment of diaphyseal fractures of humerus treated by titanium elastic nails in adult age group. J Clin Diagn Res. 2017 May;11(5):RC01-RC04. doi: 10.7860/ JCDR/2017/26449.9812

7. Clement ND. Management of humeral shaft fractures; nonoperative versus operative. Arch Trauma Res. 2015 Jun 20; 4(2):e28013. doi: 10.5812/atr.28013v2

8. Carroll EA, Schweppe M, Langfitt M, Miller AN, Halvorson JJ. Management of humeral shaft fractures. J Am Acad Orthop Surg. 2012 Jul;20(7):423-33. doi: 10.5435/JAAOS-20-07-423

9. Sahu RL, Ranjan R, Lal A. Fracture union in closed interlocking nail in humeral shaft fractures. Chin Med J (Engl). 2015 Jun 5;128(11):1428-32. doi: 10.4103/0366-6999.157630

10. Lin J, Inoue N, Valdevit A, Hang YS, Hou SM, Chao EY. Biomechanical comparison of antegrade and retrograde nailing of humeral shaft fracture. Clin Orthop Relat Res. 1998 Jun; (351):203-13.

11. Rodrigues-Merchan EC. Compression plating versus Hackethal nailing in closed humeral shaft fractures failing nonoperative reduction. J Orthop Trauma. 1995 Jun;9(3):194-7.

12. Robinson CM, Bell KM, Court-Brown CM, McQueen MM. Locked nailing of humeral shaft fractures. Experience in Edinburgh over a two-year period. J Bone Joint Surg Br. 1992 Jul;74(4):558-62.

13. Brumback RJ, Bosse MJ, Poka A, Burgess AR. Intramedullary stabilisation of humerus shaft fractures in patients with multiple trauma.J Bone Joint Surg Am. 1986 Sep;68(7):960-70.

14. McCormack RG, Brien D, Buckley RE, McKee MD, Powell J, Schemitsch EH. Fixation of fractures of the shaft of the humerus by dynamic compression plate or intramedullary nail: a prospective randomized trial. J Bone Joint Surg Br. 2000 Apr;82(3):336-9.

15. Liu GD, Zhang QG, Ou S, Zhou LS, Fei J, Chen HW, et al. Meta-analysis of the outcomes of intramedullary nailing and plate fixation of humeral shaft fractures. Int J Surg. 2013; 11(9):864-8. doi: 10.1016/j.ijsu.2013.08.002

16. Changulani M, Jain UK, Keswani T. Comparison of the use of the humerus intramedullary nail and dynamic compression plate for the management of diaphyseal fractures of the humerus. A randomised controlled study. Int Orthop. 2007 Jun;31(3):391-5. doi: 10.1007/s00264-006-0200-1

17. Han KJ, Lee DH, Bang JY. Do cerclage cables delay the time to bone union in patients with an unstable humeral shaft fracture treated with intramedullary nails? Yonsei Med J. 2017 Jul;58(4):837-41. doi: 10.3349/ymj.2017.58.4.837

18. Mahabier KC, Van Lieshout EM, Van Der Schaaf BC, Roukema GR, Punt BJ, Verhofstad MH, et al. Reliability and repro- ducibility of the OTA/AO classification for humeral shaft fractures.J Orthop Trauma. 2017 Mar;31(3):e75-e80. doi: 10.1097/ BOT.0000000000000738

19. Litrenta J, Tornetta $\mathrm{P} 3^{\text {rd }}$, Mehta S, Jones C, O’Toole RV, Bhandari $\mathrm{M}$, et al. Determination of radiographic healing: an assessment of consistency using RUST and Modified RUST in metadiaphyseal fractures. J Orthop Trauma. 2015 Nov; 29(11):516-20. doi: 10.1097/BOT.0000000000000390

20. Kivi MM, Soleymanha M, Haghparast-Ghadim-Limudahi Z. Treatment outcome of intramedullary fixation with a locked rigid nail in humeral shaft fractures. Arch Bone Joint Surg. 2016 Jan;4(1):47-51.

21. Bhandari M, Devereaux PJ, McKee MD, Schemitsch EH. Compression plating versus intramedullary nailing of humeral shaft fractures - a meta-analysis. Acta Orthop. 2006 Apr; 77(2):279-84. doi: 10.1080/17453670610046037

22. Seidel H. Humeral locking nail: a preliminary report. Orthopedics. 1989 Feb;12(2):219-26.

23. Crates J, Whittle AP. Antegrade interlocking nailing of acute humeral shaft fractures. Clin Orthop Relat Res. 1998 May; (350):40-50.

24. Chen F, Wang Z, Bhattacharyya T. Outcomes of nails versus plates for humeral shaft fractures: a Medicare cohort study. J Orthop Trauma. 2013 Feb;27(2):68-72. doi: 10.1097/BOT. 0b013e31824a3e66

25. Fernandez FF, Matschke S, Hulsenbeck A, Egenolf M, Wentzensen A. Five years' clinical experience with the unreamed humeral nail in the treatment of humeral shaft fractures. Injury. 2004 Mar;35(3):264-71.

26. Blum J, Janzing H, Gahr R, Langendorff HS, Rommens PM. Clinical performance of a new medullary humeral nail: antegrade versus retrograde insertion. J Orthop Trauma. 2001 JunJul;15(5):342-9.

27. Cheng HR, Lin J. Prospective randomized comparative study of antegrade and retrograde locked nailing for middle humeral shaft fracture. J Trauma. 2008 Jul;65(1):94-102. doi: 10.1097/ TA.0b013e31812eed7f

28. Blum J, Karagül G, Sternstein W, Rommens PM. Bending and torsional stiffness in cadaver humeri fixed with a self-locking expandable or interlocking nail system: a mechanical study. J Orthop Trauma. 2005 Sep;19(8):535-42.

29. Müller LP, Suffner J, Wenda K, Mohr W, Rommens PM. Radiation exposure to the hands and the thyroid of the surgeon during intramedullary nailing. Injury. 1998 Jul;29(6):461-8.

30. Benčić I, Čengić T, Prenc J, Bulatović N, Matejčić A. Humeral nail: comparison of the antegrade and retrograde application. Acta Clin Croat. 2016 Mar;55(1):110-6. doi: 10.20471/ acc.2016.55.01.16

31. Tyllianakis M, Tsoumpos P, Anagnostou K, Konstantopoulou A, Panagopoulos A. Intramedullary nailing of humeral diaphyseal fractures. Is distal locking really necessary? Int J Shoulder Surg. 2013 Apr;7(2):65-9. doi: 10.4103/0973-6042.114233 
32. Williams PR, Shewring D. Use of an elastic intramedullary nail in difficult humeral fractures. Injury. 1998 Nov;29(9): 661-70.

33. Baltov A, Mihail R, Dian E. Complications after interlocking intramedullary nailing of humeral shaft fractures. Injury. 2014 Jan;45 Suppl 1:S9-S15. doi: 10.1016/j.injury.2013.10.044

34. Westrick E, Hamilton B, Toogood P, Henley B, Firoozabadi R. Humeral shaft fractures: results of operative and non-operative treatment. Int Orthop. 2017 Feb;41(2):385-95. doi: 10.1007/ s00264-016-3210-7
35. Denard A Jr, Richards JE, Obremskey WT, Tucker MC, Floyd M, Herzog GA. Outcome of nonoperative vs operative treatment of humeral shaft fractures: a retrospective study of 213 patients. Orthopedics. 2010 Aug 11;33(8). doi: 10.3928/ 01477447-20100625-16

36. Mahabier KC, Vogels LM, Punt BJ, Roukema GR, Patka P, Van Lieshout EM. Humeral shaft fractures: retrospective results of non-operative and operative treatment of 186 patients. Injury. 2013 Apr;44(4):427-30. doi: 10.1016/j.injury.2012. 08.003

Sažetak

\section{PRIJELOMI DIJAFIZE HUMERUSA: LIJEČENJE ANTEGRADNIM USIDRENIM ENDOMEDULARNIM ČAVLOM S PRIMJENOM NEUTRALIZACIJSKIH VIJAKA KROZ FRAKTURNU PUKOTINU}

\section{Vidović, I. Benčic, T. Ćuti, D. Gajski, T. Čengić, M. Bekić, M. Zovak, S. Sabalić i D. Blažević}

Cilj ovoga istraživanja bio je usporediti vrijeme cijeljenja prijeloma dijafize humerusa pri liječenju s dva različita dizajna intramedularnog čavla: antegradni ukotvljeni intramedularni čavao s dodatnim ukotvljenim neutralizacijskim vijcima i bez njih. Retrospektivna studija obuhvatila je 51 bolesnika liječenog antegradnim humeralnim intramedularnim čavlima između siječnja 2015. i prosinca 2017. godine. Kriteriji uključenja u studiju bili su prijelomi proksimalne i srednje trećine dijafize humerusa. Pedeset i jedan bolesnik je ispunio kriterije uključenja: 23 bolesnika su liječena antegradnim intramedularnim čavlom s dodatnim ukotvljenim neutralizacijskim vijcima kroz mjesto prijeloma (skupina A), a 28 bolesnika je liječeno antegradnim intramedularnim čavlom bez dodatnih ukotvljenih neutralizacijskih vijaka (skupina B). Analizirana je medicinska dokumentacija i radiološke slike učinjene prije i poslije operacije. Radiološko cijeljenje prijeloma definirano je kao kortikalno premošćivanje najmanje tri od četiri korteksa u dvoprofilnim radiografima, s nestankom frakturne pukotine. Nije bilo značajne razlike u vremenu cijeljenja prijeloma između skupina ( $>0,05)$. Prema našim spoznajama, ovo je prva studija o liječenju prijeloma humerusa antegradnim intramedularnim čavlom $s$ dodatnim ukotvljenim neutralizacijskim vijcima kroz mjesto prijeloma. Hipotetsku prednost redukcije prijelomne pukotine s dodatnim ukotvljenim neutralizacijskim vijcima u svrhu poticanja cijeljenja nije potvrdila ova prva klinička studija.

Ključne riječi: Humerus; Humerus, prijelomi; Prijelom, fiksacija, intramedularna; Kosti 